\title{
Revealing Multiliteracies in English as a Foreign Language Classroom
}

\author{
Agus Khairi \\ Universitas Negeri Surabaya \\ Surabaya,Indonesia \\ aguskhairi@mhs.unesa.ac.id
}

\author{
Pratiwi Retnaningdyah \\ Universitas Negeri Surabaya \\ Surabaya,Indonesia \\ pratiwiretnaningdyah@unesa.ac.id
}

\author{
Aswandi \\ Universitas Negeri Surabaya \\ Surabaya,Indonesia \\ aswandi@unesa.ac.id
}

\begin{abstract}
Teaching English as a foreign language is aimed to give knowledge for students in facing globalisation era in which English used as international language. Therefore, teaching and learning process should take into account about multiliteracies, those are considering difference of culture of global community that uses English and multiplicity of communication that rapidly increases requires people who are able to use media and common language used in communication. To know how multiliteracies was addressed in teaching English as Foreign Language (EFL) contexts in Indonesia, this case study examined teaching and learning process in an EFL Classroom by applying pedagogy of multiliteracies framework. Result showed that teaching and learning process mostly reached three kinds of four frameworks in pedagogy of multiliteracies. Those are situated practice, overt instruction, and critical framing. Transformed practice could not be reached in teaching and learning process because it did not provide process that allows students to revise and apply what they have learned critically to be more meaningful practice. It can be concluded that English language teaching in EFL context did not address the whole categories of multiliteracies pedagogy frameworks so that students cannot acquire multiliteracies competence.
\end{abstract}

Keywords-multiliteracies, English language teaching, EFL classroom

\section{INTRODUCTION}

Literacy has become a significant issue in Indonesian educational system since School Literacy Movement (Gerakan Literasi Sekolah) being launched by the Indonesian Ministry of Education and Culture in 2015. It was aimed to foster students' literacy competence in Indonesia. To achieve the aim, in 2013 curriculum literacy competence has been considered to be the goal of learning activity. That is why English curriculum was designed to guide students to use some kind of texts for basic literacy need [1]. English curriculum applied text-based learning to achieve students' competence to communicate using English in their social context.
Nowadays, literacy is not only about reading and writing, it is broaden as a social practice based on New Literacy Studies' view [2] "how literacy used and what people do with literacy in everyday live". Moreover, the concept of literacy as a social practice gives an understanding that literacy is connected to other things in human's social life. It is not just about writing and book, but how the understanding gained from reading can be used in daily life.

Related to the goal of the curriculum, English language teaching has to be aware of global context to make students engage within the current era and to increase students' competency to use language they learned in some goals of communication in daily life [1]. It relates to term of multiliteracies proposed by The New London Group [3] in which literacy take into account of multiplicity of communication channels and media and the increasing of salience of cultural and linguistic diversity; refer to a global society. To apply it in teaching process, NLG proposed framework known as Pedagogy of Multiliteracies in which literacy pedagogy take into account of developing global societies, diverse of culture and linguistic, as well as a plurality of text that used in global society and associated with the development of technology and media.

Some studies conducted in term of pedagogy of multiliteracies. Shoffner, Oliveira and Angus [4], using a case study approach to examine teacher's understanding of literacy, views on enacting literacy in the classroom and efforts to engage students in multiliteracies. The results showed that the English teachers did their best in today's demanding educational atmosphere related to multiliteracies. Xing Meng Ms. [5], this case study observed live story of a one-grade teacher who has implemented multiliteracies pedagogy in her classroom. The study revealed that the teacher implemented multiliteracies to understand and value the diverse identity of learner and connect their experience beyond the school by integrating multimodal instruction. Boche [6], examined five first-year teachers' understandings of and experiences with 
multiliteracies. This narrative inquiry showed that the English teachers considered the $21^{\text {st }}$ century demands of teaching such as multimodal text and enactment of technology. All of these studies showed that how multiple texts have an important role in engaging students learning in the classroom. However, those studies conducted in English as first language.

A research that analyzed materials of English Language Teaching at a Private Japanese university conducted by Rowland, Canning, Faulhaber, Lingle, and Redgave [7]. The result revealed that the majority of the analysed materials target the knowledge process experiencing, while few materials require students to conceptualise or analyse information. From the result, the author stated that the approach can be effectively used as an instrument to analyse the meaning-making opportunities as the goal of multiliteracies approach in teaching, to students by ELT literacy materials. However, the study did not depict the classroom activity because just analyzed the materials. In Indonesia context, a study that used The New Literacy Studies platform is rare. Some studies have been conducted by using this platform are studies about literacy practice in migrant worker community and "street children" community [8]. The studies did not conduct in classroom of English language teaching. Therefore, there is a need to investigate how EFL classroom addresses multiliteracies in 2013 curriculum context.

\section{METHOD}

This study employed a qualitative design in which produced descriptive data got from the subject of the study. Qualitative research refers to research that uses descriptive data as basic analysis rather than statistical procedural [9]. A case study is going to employed to answer the research questions, because of this study is going to examine the particular event in particular institution [10] that is a classroom. To collect the data, observation was conducted in an eighth grade English classroom of Junior High School that implemented 2013 curriculum by employing a check list consists of subcategories of multiliteracies adapted from Main [11]. Observation was conducted in one meeting only. To gain a fuller perspective on the situation is being investigated, the data triangulation were conducted [12], therefore in this study also employed field note to give more information about classroom activities observed by the researcher. After collecting the data, the data were analyzed and displayed based on the four categories of multiliteracies to draw the conclusion.

\section{RESULTS}

From the observations found that not all of form of multiliteracies categories fulfilled in the teaching and learning process. Situated practice was fulfilled completely while Overt instruction is only fulfilled two of three subcategories. Critical framing is only fulfilled two of four subcategories whereas transformed practice did not fulfil at all Thus, teaching and learning process conducted by the English teacher did not address all of the forms of multiliteracies category.
The result of classroom observation can be seen in the table 1 .

In detail, the following will be explained the result of classroom observation:

\section{A. Situated Practice}

There were five subcategories included in this form of multiliteracies. All of those subcategories conducted by the English teacher in two meetings in the classroom.

TABLE I. TABLE I. RESULT OF THE CLASSROOM OBSERVATION

\begin{tabular}{|c|c|c|}
\hline $\begin{array}{c}\text { Form of } \\
\text { Multiliteracies }\end{array}$ & $\begin{array}{c}\text { Subcategory of Form of } \\
\text { Multiliteracies }\end{array}$ & $\begin{array}{c}\text { Check } \\
\text { List }\end{array}$ \\
\hline \multirow{5}{*}{ Situated Practice } & Motivate students to learn & $\sqrt{ }$ \\
\hline & $\begin{array}{l}\text { Meaningful practice in community of } \\
\text { learners }\end{array}$ & $\sqrt{ }$ \\
\hline & Role model, teacher or peer & $\sqrt{ }$ \\
\hline & $\begin{array}{l}\text { Reference student's previous and } \\
\text { current experience }\end{array}$ & $\sqrt{ }$ \\
\hline & Including student's native language & $\sqrt{ }$ \\
\hline \multirow{3}{*}{ Overt Instruction } & $\begin{array}{l}\text { Scaffold student's learning (guided } \\
\text { practice) }\end{array}$ & $\sqrt{ }$ \\
\hline & Use of metalanguage & $\sqrt{ }$ \\
\hline & $\begin{array}{l}\text { Use of Multimedia or technology to } \\
\text { enhance instruction }\end{array}$ & \\
\hline \multirow{4}{*}{ Critical Framing } & $\begin{array}{l}\text { Build student's critical literacy } \\
\text { (critical thinking skill) }\end{array}$ & \\
\hline & Relates learning into social contexts & \\
\hline & $\begin{array}{l}\text { Frame learners' growing mastery, } \\
\text { conscious control and understanding }\end{array}$ & $\sqrt{ }$ \\
\hline & $\begin{array}{l}\text { Social context and purposes: students } \\
\text { begin to position themselves in terms } \\
\text { of historical, social, cultural, political, } \\
\text { cultural and ideological relations }\end{array}$ & $\sqrt{ }$ \\
\hline \multirow{3}{*}{$\begin{array}{l}\text { Transformed } \\
\text { Practice }\end{array}$} & $\begin{array}{l}\text { Transfer of learning from one to } \\
\text { another context (reflective practice) }\end{array}$ & \\
\hline & $\begin{array}{l}\text { Implementing the previous } \\
\text { understanding they learned into } \\
\text { contextual practice }\end{array}$ & \\
\hline & Contextualized assessment & \\
\hline
\end{tabular}

\section{1) Motivate Students to Learn}

In the first meeting, teacher motivated students in the beginning activities by asking students to perform special yells in English for their class. Then, teacher explained the purpose of the current learning activity.

Teacher : What topic did you learn last week? I will give you point if you can answer my question.

\section{Student A : Holiday Mam. \\ Student B : Julia’s Holiday Mam. \\ Teacher : Yes, that's right.}

2) Reference Students' Previous and Current Experience

Before continuing the current learning topic, teacher tried to link students into the topic they will learn. Teacher asked students about previous experience they know relates to the topic. In the first meeting, teacher asked about what they know about folktale. 
Teacher : Today, we are going to learn about folktale. What do you know about folktale?

Students : Dongeng, cerita rakyat $\mathrm{Bu}$.

Then Teacher asked some question relate to the topic:

"Do you like folktale?"

"What kinds of folktale have you ever heard?"

"Who told you that folktale?"

In this activity, teacher tried to link students' previous experience got from out of school. What they knew about folktale got from their experience in their environment such as their family at home, watch, and listen through mass media and other resources.

\section{3) Role Model}

In the classroom teacher as role model in performing English based on the topic they learned. Before asking students to do the task, examples were given in order to make students understand how they will do the task. Teacher performed how to ask question about folktale with appropriate pronunciation and intonation in English.

Then Teacher asked some question relate to the topic:

"Do you like folktale?"

"What kinds of folktale have you ever heard?"

"Who told you that folktale?"

\section{4) Meaningful Practice in Community Learner}

In learning activity, teacher asked students to do the task in a group in order to make meaningful activity. In pair, students practiced to ask each other about folktale like example that teacher gave to them.

Teacher : Now, practice with your partner to ask and answer about folktale. Do with your friend beside you.

Students practice question and answer in group of two based on example given by teacher.

Most of the activities in the classroom were done by grouping the students into two or four students in a group. By doing these, teacher tend to give experience for the students to interact each other in community learner. By interacting with other students, learning activity will be more meaningful for students because they can practice what they knew and get input from other students at once.

\section{5) Including Students' Native Language}

In conducting teaching and learning, sometimes teacher used Bahasa Indonesia and Sasak (local language) to make the explanation clearer. Students' native languages were rarely included; they were used to give more explanation that difficult to understand by the students in Bahasa. Besides giving more explanation, students' native languages were used to make the topic related to students' basic knowledge.

\section{B. Overt Instruction}

There were three subcategories included in this form of multiliteracies. Those were scaffold students' learning, use metalanguage, and use of multimedia or technology to enhance instruction. From those subcategories, there were only two of them fulfilled whereas one of subcategories did not fulfill. That was the use of multimedia or technology to enhance instruction.

\section{1) Scaffold Students' Learning}

Teacher guided the students in every learning activity to make sure they do the task well. In giving material, the teacher did it step by step. When students did the task, the teacher came to each group to check students work and gave guidance if there were a mistake made by the students. Scaffolding was given from the beginning until the end of classroom activity by considering the needs of students to do the task either individual or group. Some activities conducted to scaffold students learning in first meeting.

- Teacher explain generic structure of the narrative text

- Students are invited to the front and then identifying generic structure of narrative text on white board

- Students are asked to find information about generic structure of narrative text

2) The Use of Metalanguage

Metalanguage used to give understanding to the students about the topic and make it simpler to talk. Metalanguage that teacher provided in conducting teaching and learning aimed to give simple word related to the topic. In this case, the metalanguage is like a generic structure, simple past tense, and conjunction. All of the terms used in learning activity related to the topic that is discussed in the classroom activity.

3) Use of Multimedia or Technology to Enhance Instruction

When this case study was conducted, the teacher did not provide multimedia or technology in conducting teaching and learning activity. The teacher only provided the material in printed base and displayed other materials in the whiteboard. Some materials for students that did in the task also used the printed base material. Some pieces of paper delivered to the students contain students' worksheet when doing the task.

\section{Critical Framing}

There are four subcategories included in this form of multiliteracies. Those were build student's critical literacy, relates learning into social context, frame learner's growing mastery, conscious control, and social context and purpose. From two meetings in the classroom conducted by the teacher, there were two subcategories fulfilled and two of them did not fulfil by the teacher, those were build students' critical literacy and relates learning into social context. 


\section{1) Build Student's Critical Literacy (Critical Thinking Skill)}

In conducting teaching and learning, the teacher did not conduct an activity that relates to build students' critical literacy. Teacher only asked students to get value from the story without criticize deeply about the content and other hidden meaning in the story.

\section{2) Relates Learning into Social Contexts}

In conducting teaching and learning activity in the classroom, the teacher did not take into account about students' social context. Either material or activity did not relate to the $21^{\text {st }}$ century as current students' learning social context. All of the material provided in form of printed base only, there was no material provided in the multimodal text. In doing the task, students were not engaged in activity that used multimedia and produce multimodal text. Even the stories provided by the English teacher got from some online resources, it can not be categorized relate into social context because students were not involved. That was just done by English teacher to provide the learning material.

3) Frame Learners' Growing Mastery, Conscious Control and Understanding

In the end of the main activity, the teacher gave correction and reinforcement about the topic. Corrections were given to give evaluation for students' work they did while practice either individual practice or group practice. Reinforcement was given by repeating the material and explaining additional information relates to the topic.

Teacher : OK students, we have learned about narrative text. the generic structure of narrative text are orientation, complication, resolution, reorientation. Language features used in narrative text are simple past tense, temporal conjunction, such as once upon a time, one day, long time ago. Time sequence conjunctions: then, after that, when, finally, etc.

\section{4) Social Context and Purposes}

Teacher asked the student about what can be learned from the story they red and discussed in the classroom. The teacher told the students the importance of learning narrative text, especially Indonesian folktale. In this case, what can they learn from the story of Malin Kundang.

Teacher : Well, after reading the story of Malin Kundang, what can we learn from the story?

Students : tidak boleh durhaka kepada ibu

Teacher : What is durhaka in English? Open your dictionary, please!

Students : rebellious, Mam

Teacher : Right, we are forbidden to be rebellious to our mother.

\section{5) Transformed Practice}

This category did not fulfil in learning activity conducted by the English teacher. The teacher did not conduct activities related to the new form of practice in new context. The output of the task done by the students did not reflect new design of the text differ with previous design. Texts produced by students were still in form of traditional printed text without modification referred to multimodal text as required by multiliteracies.

\section{DISCUSSION}

Findings revealed how multiliteracies pedagogy addressed in the learning activity conducted by the English teacher in one meeting. Multiliteracies implemented in some activities during teaching and learning process. Majority subcategories included in the first three forms of multiliteracies, situated practice, overt instruction, and critical framing, are implemented. A form of multiliteracies, that is transformed practice, was not implemented in teaching and learning process.

Situated practice was implemented by conducting all of the subcategories that include within this form of multiliteracies. Teacher engaged students to learn by immersing them into learning practice within the group of students. Before this immersion, teacher linked students to the topic by motivating them and referring with the prior knowledge they have. This in line with principle of 2013 curriculum in which teaching and learning take into account about students' cultural background as a foundation to learn current topic in the classroom[13]. Motivating students conducted in the first activity before going forward to the main activity. This activity in line with what Main [11] stated that "the NLG believe that students need to be motivated to learn. Teachers in this study described motivation as a crucial effective consideration." Accordingly, motivation is needed and important thing in implementing multiliteracies.

Besides motivating students, meaningful practice is one of the main purposes in situated practice. By implementing situated practice, the purpose of values experience each students bring to the classroom and the need of a forum to share and express students experience are provided [5]. Relates to this, teacher provides practice mostly in a group activity in order to give experience for students to interact each other and express their prior knowledge based on their background and experience [2]. In meaningful practice, students are prepared with the knowledge that will be used in next practice or future learning. It means that meaningful practice can create a positive foundation for future learning [11].

To gain a better understanding of students, the teacher used student's native language to explain more about the topic that students difficult to understand. However, finding showed that the use of native language was very rare. Even in teaching English as a foreign language should give role model to use English but in multiliteracies view, the use of native language to enhance students' understanding is allowed. It can help students to understand more about a certain part of the topic that difficult to understand. Larry Condelli in his study [2] 
stated that "when the teacher used native language as part of instruction to clarify and explain points, students showed faster growth in both reading comprehension and oral communication skills". Clearly, students, native language can help to explain more about the points of topic in learning English.

Overt instruction is provided to aid and improves meaningful practice in situated practice. Relate to this category of multiliteracies, teacher implemented two of three subcategories, scaffold students' learning and the use of metalanguage, whereas the use of multimedia and technology was not implemented. Teacher scaffold students learning by guiding students in understanding of the text gradually and provided some specific word relate to the topic. Guidance is clearly given either before or while students did the task. What teacher did in scaffolding learning to avoid traditional pedagogy that makes teacher as a centre of activity and make students actively learn about the topic [14]. Moreover, by designing activity that makes students actively engage in classroom activity can make students put more time and effort to their work [5].

As mentioned before, the use of multimedia and technology to enhance instruction did not fulfil in this category of the form of multiliteracies. The teacher did not provide any multimedia device that can help in delivering learning material. Even though in principle of 2013 curriculum requires integrating information and communication technology to improve learning efficiency and effectiveness [13]. This finding contrast with the finding of a study that revealed the use of technology to increase students understanding and motivation in doing the task given [15]. The impact of deficit use of technology in the classroom is that teacher can not provide multiple texts or provide traditional text using multimedia. In this case, even teacher provided traditional print text, but can be presented by media and technology to diversify classroom text [4] if teacher enacted media and technology in classroom activity.

The next category to be implemented in term of multiliteracies view is critical framing. Relate to this category, findings showed two subcategories were fulfilled in teaching and learning process conducted by the English teacher during two meetings. Findings uncovered that teacher implemented this category by giving reinforcement to frame students understanding about the topic then encourage students to reveal the meaning of the text in social life. It is in line with Mills [16] who stated that "in critical framing, students are guided to analyse design critically in relation to whose interests are served by the meaning (ideology), and by considering the audience to whom the meanings are directed". By doing the activities, the teacher tried to encourage students to grow their understanding of the learning materials and the purpose of learning such kind of the text such as structure and function of the text. This is in line with Mills [16] in his study in which students were encouraged to be able to understand the structure, function, connections and contexts of the design of meaning by analysing text functionally.

Furthermore, related to the critical framing category, the teacher did not conduct it completely because two of the subcategories of it did not fulfil. Those categories are relates learning into social context and build students critical literacy. In term of relates learning into social context, the teacher did not take account the $21^{\text {st }}$-century context where students life nowadays. It means that learning did not relate to larger social context. In contrary, Main [11] found that teacher who conducted critical framing by framing students learning within a larger social context. Furthermore, Main also found that discussions were used to examine multiple perspectives and potential roles for students to contribute to society.

Build students' critical literacy, a subcategory of critical framing, did not provide in relating to the multiliteracies. Even students were encouraged to get the meaning and function of the text in their social life but it was not in depth analysing as required by critical framing, that is "the ability to analyse explicit and implicit motives, agendas and actions behind a piece of knowledge (analyzing critically) [16]. Teacher only invited students to analyze the function of the text and did not criticize deeply the value and the goal of text.

The last category of the form of multiliteracies is transformed practice. Finding revealed there were no subcategories fulfilled in teaching and learning process conducted by the English teacher. There were no activities that relate to transformed practice during two meetings observed by the researcher because learning activity conducted did not provide reflective practice, means that new practice that differs from they got in situated practice process [3]. Teacher provides the activity that produces printed text in the situated practice and in the end of activity students produce printed text also, not a new one by new practising. It means that there was no reflective practice provided by the English teacher in teaching and learning process. Although in 2013 curriculum did not mention new mode of the text explicitly as an output of learning but by requiring the integration of ICT in learning activity means that multimodal text can be produced. Students can be guided to make new mode of text as reflective practice of the previous practice. But the finding showed that the teacher did not provide learning activity that relate to produce multimodal text. Therefore, can be concluded that transformed practice did not implement transformed practice category.

\section{CONCLUSION}

In teaching and learning process, multiliteracies were addressed by some activities conducted by the teacher. The situated practice was addressed by conducting learning activity that focuses on how students involved in meaningful practice by bringing their previous experience in the group activity. Subcategories in this form of multiliteracies were most addressed because teacher completely addressed all of the subcategories within it. The overt instruction was addressed by scaffolding students in learning activities either individual or group activities. The teacher did not provide technology and multimedia devices in conducting teaching and learning even it can be very helpful to enhance the instruction. Teacher addressed critical framing by encouraging students to reveal the meaning of the text that can be learned but did not guide the students criticize deeply to practice the critical literacy. Transformed practice did not address by the teacher, because there were no activities that relate to this 
category of multiliteracies. To conclude, even though the teacher conducted teaching and learning process in English as a Foreign Language in 2013 curriculum context, the form of multiliteracies did not completely addressed.

\section{REFERENCES}

[1] Kemdikbud, Silabus Mata Pelajaran Sekolah Menengah Pertama/Madrasah Tsanawiyah (SMP/MTs): Mata Pelajaran Bahasa Inggris. Jakarta: Kemdikbud, 2016.

[2] K. Pahl and J. Rowsell, Literacy and Education. London: Paul Chapman Publishing, 2005.

[3] The New London Group, "A Pedagogy of Multiliteracies: Designing social futures," in Multiliteracies: Literacy learning and the design of social future, B. Cope and M. Kalantzis, Eds. London \& New York: Routledge, 2005, pp. 9-36.

[4] M. Shoffner, L. C. de Oliveira, and R. Angus, "Multiliteracies in the secondary english classroom: Becoming literate in the 21st century," English Teach., vol. 9, no. 3, pp. 75-89, 2010.

[5] X. M. Ms, "A Pedagogy of Multiliteracies into Practice: A Case Study in One Grade One Literacy Classroom," The University of Western Ontario, 2016.
[6] B. Boche, "Multiliteracies in the Classroom : Emerging Conceptions of First- Year Teachers," J. Lang. Lit. Educ., vol. 10, no. 1, pp. 114-135, 2014.

[7] L. Rowland, N. Canning, D. Faulhaber, W. Lingle, and A. Redgrave, "A multiliteracies approach to materials analysis," Lang. Cult. Curric., vol. 27, no. 2, pp. 136-150, 2014.

[8] S. Dewayani and P. Retnaningdyah, Suara dari Marjin: Literasi sebagai Praktik Sosial. Bandung: PT Remaja Rosdakarya, 2017.

[9] A. Mackey and S. M. Gass, Second Language Research: Methodology and Design. London: Lawrence Erlbaum Associates Publisher, 2005.

[10] K. Richards, Qualitative Inquiry in TESOL. New York: Palgrave Macmillan, 2003.

[11] K. L. Main, "Mapping Multiliteracies onto the Pedagogy of K-12 Teachers," University of Toronto, 2011.

[12] M. B. Miles, A. M. Huberman, and J. Saldana, Qualitative Data Analysis: A Methods Sourcebook, 3rd ed. USA: SAGE Publications, Inc., 2014.

[13] Kemdikbud, Dokumen kurikulum 2013, no. Desember. Jakarta, 2012.

[14] M. Ganapathy, "Using Multiliteracies to Engage Learners to Produce Learning," Int. J. e-Educ. e-Buisines, e-Management e-Learn., vol. 4, no. 6, pp. 410-423, 2014.

[15] N. Cooper, L. Lockyer, and I. Brown, "Developing multiliteracies in a technology-mediated environment," EMI. Educ. Media Int., vol. 50, no. $2,2013$.

[16] K. Mills, "Critical Framing in a Pedagogy of Multiliteracies," Aust. Assoc. Teach. English Natl. Conf. 2006, vol. 84, no. 11, p. 15, 2006. 